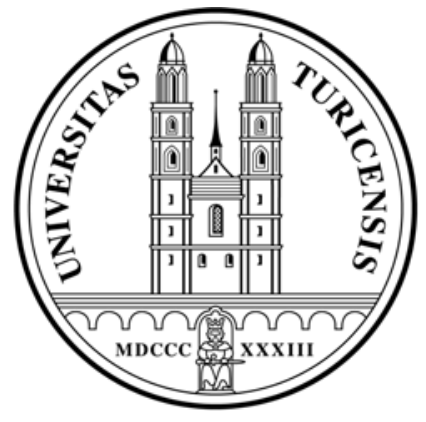

Institute for Empirical Research in Economics

University of Zurich

Working Paper Series

ISSN 1424-0459

Forthcoming in: Economica

Working Paper No. 135

Being Independent is a Great Thing: Subjective Evaluations of Self-Employment and Hierarchy

Bruno S. Frey and Matthias Benz

September 2006 
Forthcoming in: Economica

\title{
BEING INDEPENDENT IS A GREAT THING: SubJective Evaluations Of Self-Employment AND HIERARCHY*
}

\author{
Matthias BenZ and Bruno S. Frey
}

Final version, September 2006

\begin{abstract}
One can be independent, or subject to decisions made by others. This paper argues that this difference, embodied in the institutional difference between the decisionmaking procedures "market" and "hierarchy", affects individual well-being beyond outcomes. Taking self-employment as an important case of independence, it is shown that the self-employed derive higher satisfaction from work than people employed in organizations, irrespective of income gained or hours worked. This is evidence for procedural utility: people do not only value outcomes, but also the processes leading to outcomes. (84 words)
\end{abstract}

Keywords: institutions, market, hierarchy, self-employment, job satisfaction, procedural utility

JEL-Codes: D00, M54, J23, J81, L22

\footnotetext{
* Institute for Empirical Research in Economics, University of Zurich, Winterthurerstr. 30, CH-8006 Zürich; Tel.+41 163437 31,Fax.+41 163449 07, email: matbenz@iew.unizh.ch, bsfrey@iew.unizh.ch. We would like to thank an anonymous referee, Gary Becker, David Blanchflower, Paul DiMaggio, Henry Hansmann, Reto Jegen, Thomas Lindh, Simon Lüchinger, Stephan Meier, Petra Moog, Felix Oberholzer, Andrew Oswald, Alois Stutzer, Tom Tyler, Burton Weisbrod, Todd Zenger and participants at various conferences and research seminars for helpful comments. This study has been realized using data collected by the German Socio-Economic Panel Study (SOEP) at the German Institute for Economic Research (DIW), Berlin, by the British Household Panel Survey, made available through the ESRC Data Archive, and by the Swiss Household Panel, a project financed by the Swiss National Science Foundation Program, SPP, „Switzerland Towards the Future" (Grant no. 5004-53205).
} 


\section{Self-Employment Provides Procedural Utility}

The economic research on happiness has identified the major determinants of self-reported subjective well-being or happiness. Among the many factors systematically influencing it, employment stands out. Persons who are unemployed are much less happy than other persons, even when other influences such as lower income are controlled for (e.g. Clark and Oswald, 1994; Winkelmann and Winkelmann, 1998; Clark et al., 2001). Being employed seems to be a value over and above the income it generates.

This paper argues that there is another, so far largely neglected aspect linking happiness and employment: self-employment provides "procedural utility". Procedural utility means that people not only value outcomes, but also the conditions and processes leading to outcomes (Frey et al., 2004; Benz, 2007). Individuals derive procedural utility from being self-employed because it gives them a higher measure of self-determination and freedom. In contrast, persons in dependent employment have to obey orders given by their superiors. Indeed, self-employment reflects the difference between the two most important decisionmaking procedures in the economy: the market and hierarchy. According to the results reported in this paper, self-employed people enjoy their position as independent actors on the market, and of not being subject to a hierarchy, mainly for procedural reasons. Clearly, such procedural utility differs from outcome utility which in the case of work relates in particular to income and working hours. As around 10 percent of all individuals gainfully employed in Western countries are self-employed, a substantial share of workers is affected. 
We study panel data from three European countries, Germany (German Socio-Economic Panel), Great Britain (British Household Panel Survey) and Switzerland (Swiss Household Panel). Using job satisfaction as a proxy measure for utility from work, it is shown that the self-employed enjoy considerably higher job satisfaction than employees in all three countries considered. These differences in job satisfaction persist if various outcome aspects of work are controlled for in the analysis, in particular income and working hours traditionally seen as sources of outcome utility in economics. Further, it is documented that differences in personality characteristics cannot explain the utility differences between selfemployed and employed workers. It may be that happier persons choose to become selfemployed, but fixed effect techniques suggest that this is unlikely to be the case. We furthermore advance the related hypothesis that satisfaction is (ceteris paribus) the lower the larger the hierarchy an employee is subject to. The empirical results are consistent with this proposition, indicating a negative relationship between firm size and job satisfaction for employees. Lastly, it is shown that both the self-employment - job satisfaction effect and the firm size - job satisfaction effect can to a large extent be explained by procedural aspects of work, namely higher autonomy and more rewarding work content, but not by outcome aspects, like work load or job security. The results thus indicate that selfemployment, and working in a smaller rather than a larger firm, are sources of procedural utility beyond material outcomes.

The present study not only provides a more general view of the utility gained from work, but has also implications for policy. Following the results reached here, the government should at least not restrict self-employment opportunities. The respective laws and regulations should be less restrictive and the bureaucratic barriers for engaging in self- 
employment should be lowered, because this would provide individuals with added procedural utility.

Section II of the paper discusses the concept of procedural utility and outlines its theoretical foundations. Section III presents the data used, and section IV contains the econometric estimates and results. Section V draws conclusions for economic theory and policy.

\section{Procedural Utility and Employment}

\section{A. The Concept of Procedural Utility in Economics}

Procedural utility means that individuals do not only care about outcomes, as usually assumed in economics, but also value the processes and conditions leading to outcomes. People do not only care about the 'what', but also about the 'how', or they value the 'means' beyond the 'ends'. The concept of procedural utility aims at integrating an aspect of human utility into economics that has largely been neglected in economic theory or empirical research (for surveys, see Frey et al., 2004; Benz, 2007).

Procedural utility is a relevant concept for economics in particular because institutions are a source of procedural utility. Institutions are understood as rules or procedures with which decisions are taken. At the level of society, the most important formal systems for reaching decisions are the price system (market), democracy, hierarchy, and bargaining (Dahl and Lindblom, 1953). Previous research has pointed to the possibility that individuals derive procedural utility from institutions. For example, a large literature in the social sciences, especially in psychology, political science and sociology, attributes a positive value to political participation possibilities, as they enhance individuals' perception of self- 
determination (for an extensive survey see Lane, 2000, chapter 13). Citizens may reap procedural utility from democracy over and above the outcome generated in the political process, because it provides a feeling of being involved and having political influence, as well as a notion of inclusion, identity and self-determination. Frey and Stutzer (2005) empirically show for the case of Switzerland that citizens reap such procedural utility from extended democratic participation rights.

With respect to work and production, the two most fundamental decision-making mechanisms used in society are the market and hierarchy (Williamson, 1975, 1985). Hierarchy means that production and employment is integrated into an organization, and decisions are characterized by some degree of authority. In contrast, the defining characteristic of the market is that people take their decisions independently, based on mutual agreement. The procedural utility concept suggests that the institutions of market and hierarchy may affect human well-being beyond material outcomes.

\section{B. Theoretical Foundations of Procedural Utility}

In order to derive testable hypotheses, it is necessary to outline the theoretical foundations of the procedural utility concept. Procedural utility emerges because individuals have a basic psychological need for self-determination. In psychology, three aspects of selfdetermination have been identified as crucial elements of human well-being: autonomy, competence and relatedness (for a survey, see Ryan and Deci, 2000). The desire for autonomy encompasses the experience to self-organize one's own actions or to be causal. The need for competence refers to the propensity to control the environment, to experience oneself as capable and effective, and to put one's abilities to use. And the need for 
relatedness refers to the desire to feel connected to others, and to be treated as a respected group member within social groups.

Different procedures and institutions can be expected to provide different procedural goods serving these innate needs. To the extent that procedures fulfill this role, they contribute to individual well-being beyond outcomes traditionally studied by economists. Psychological theory stresses, for example, that procedures providing individuals with autonomy are not valued so much because they lead to better outcomes, like a higher income, but rather because having control over one's actions satisfies a basic psychological need of human beings (e.g. Ryan and Deci, 2000; Lind and Tyler, 1988). In this sense, people may be satisfied with an unfavorable outcome if the procedure applied was 'good', and a favorable outcome might provide them with little overall satisfaction if the procedure that brought it about was 'bad'.

\section{Derivation of Hypotheses}

The theoretical procedural utility concept outlined can be applied to the institutional difference between market and hierarchy. In general, possibilities of self-determination are strongly related to the market mechanism and generally restricted under hierarchy. When acting directly on the market, individuals have more freedom to choose the actions and the tasks they want to perform, in contrast to a situation when they are subject to hierarchical decision-making.

The main idea of this paper is to approximate the institutional difference between the market and hierarchy by comparing self-employed and employed people. Self-employed people act as independent actors on the market, whereas people employed in organizations 
are subject to hierarchical decision-making. As a consequence, we formulate the first hypothesis:

H1: Self-employed people derive higher procedural utility from work than people employed in organizations.

Self-employment indeed represents in many respects a suitable field for studying procedural utility from the market vs. hierarchy. People who are self-employed or employed are essentially engaged in the same labor markets, and they perform similar production activities. This makes the two groups comparable. Of course, self-employed people face some other external constraints, in particular those directly imposed by the market, but also by government laws and regulations. These differences in external constraints, however, make the life of self-employed rather harder than easier. For example, acting as an independent contractor on the market carries more risk, and government regulations impose more administrative work on the self-employed. To the extent that these aspects are valued negatively by individuals, they are likely to decrease the utility of the self-employed in comparison to employees. In contrast, following our theoretical predictions, the self-employed will enjoy higher procedural utility from work than employees because of their greater possibilities for self-determination.

A related, second hypothesis can be derived with respect to the size of a firm. If the intensity of hierarchy increases with firm size, then the following relationship should hold:

$\mathrm{H} 2$ : People working in smaller firms enjoy higher procedural utility than people working in larger firms.

There are several reasons why a positive relationship between the intensity of hierarchical decision-making and firm size may be expected. First, the average employee in a small 
organization is typically subject to less hierarchical layers than the average employee in a large organization. Second, individual possibilities of self-determination are likely to decrease more than proportionally with the number of hierarchical layers, because large hierarchies rely more on centralized decision making (e.g. Schminke et al., 2000), on more formalized work processes (e.g. Pugh et al., 1968), and are more prone to "micro-politics" (e.g. Pfeffer, 1981; Cropanzano et al., 1995). Thus, if procedural utility is strictly decreasing in the intensity of hierarchy, there should be a negative relationship between firm size and procedural utility.

\section{Comparison to Traditional Economic Theories}

The two hypotheses derived clearly contrast with traditional economic theories of work and employment. In standard economics, it is typically assumed that work is as a source of disutility, because it represents foregone leisure, and income gained by working is considered to be a source of utility, because it can be used for consumption. In contrast to this traditional view, the procedural utility approach stresses that work is not always a source of disutility for individuals; rather, people may derive satisfaction from working, or "consume" on the job, in particular if they have extended possibilities for selfdetermination.

The procedural utility view, however, is strongly related to the approach of compensating wage differentials well established in labor economics. Procedural utility represents a form of non-monetary work benefit that should be reflected in wage differentials between people who enjoy high or low procedural utility at work. There are indeed two studies applying such an approach. Hamilton (2000) convincingly shows that self-employment does not pay, 
i.e. the self-employed seem to be willing to forego income in exchange for being independent. Similarly, Moskovitz and Vissing-Jorgensen (2002) document that selfemployed persons accept lower risk-adjusted returns on their entrepreneurial investments than what could be obtained by investing in the public stock market. Thus, evidence from compensating wage and return differentials suggest that self-employment provides nonmonetary benefits. However, the studies mentioned do not investigate in detail what these benefits consist of. Quite generally, the literature on wage differentials has not paid much attention to identifying procedural characteristics of work, but has predominantly studied more "objective" aspects of work such as health risks (e.g. Viscusi, 1993).

\section{E. Measuring Utility}

In contrast to applying a compensating wage differential approach, the present paper uses an alternative and complementary method to document procedural utility in selfemployment. An attempt is made to measure utility directly, by using self-reported job satisfaction as a proxy variable for utility from work. Job satisfaction has been increasingly used by economists as a meaningful concept to analyze the labor market (e.g. Hamermesh, 1977; Blanchflower and Oswald, 1999; Clark, 2001; for a survey see Warr, 1999). Its growing use reflects a more general change that economics has experienced in recent years. Utility is increasingly seen as directly measurable by using self-reported satisfaction measures as a proxy. For example, measures of subjective well-being (or happiness) have been successfully applied in economic research (for surveys see Layard, 2005; Frey and Stutzer, 2002; Oswald, 1997). 
Job satisfaction measures have several advantages compared to the traditional study of compensating wage differentials. First, no assumptions have to be made with respect to the competitiveness of the underlying labor market. While wage differentials only reflect nonmonetary benefits from work adequately if a labor market is sufficiently competitive, nonmonetary benefits can also be detected in job satisfaction differentials if inefficiencies exist, e.g. if there are rents in the labor market (Clark, 2003; Lalive, 2002). Second, job satisfaction measures do not require strong assumptions with respect to individual rationality. For example, it has been argued that individuals systematically overvalue "decision utility" relative to "experienced utility" when predicting future utility, which can lead to systematic errors e.g. in the choice of a workplace (Kahneman et al., 1997; Frey and Stutzer, 2004). Job satisfaction measures are likely to better reflect the "experienced utility" that individuals actually enjoy at the workplace, while wage differentials probably relate more to the "decision utility" that individuals take predominantly into account when deciding between two jobs or forms of employment. Job satisfaction measures also have disadvantages compared to the traditional wage differential approach. Most importantly, job satisfaction is assessed using survey questions, which may be prone to reporting biases (Betrand and Mullainathan, 2001), whereas wage differentials reflect the revealed behavior of individuals.

There already exists some research by economists indicating that self-employment is related to higher job satisfaction. Blanchflower and Oswald (1998), Blanchflower (2000), Blanchflower et al. (2001) and Kawaguchi (2002) present evidence for a positive relationship between self-employment and job satisfaction in many European countries and in the United States, without further investigating the question why the self-employed are happier with their jobs. A study by Hundley (2001) for the United States addresses this 
issue in more detail and finds that the self-employed are more satisfied with their work mainly because of more autonomy, but also because of more flexibility, skill utilization, and to some extent higher job security. This evidence is overall consistent with our first hypothesis. In the present paper, we perform a complementary analysis, investigating whether the high job satisfaction among the self-employed can be attributed to procedural utility, and whether similar reasons explain the hypothesized negative relationship between firm size and job satisfaction.

\section{DATA}

The empirical analysis is based on three major data sets from European countries: the German Socio Economic Panel Survey (GSOEP), the British Household Panel Survey (BHPS), and the Swiss Household Panel Survey (SHP). The three surveys are comprehensive sources of information on work related aspects, income, and other socioeconomic variables in Germany, Great Britain and Switzerland. Compared to other data sets previously used to test the effects of self-employment on job satisfaction (e.g. Blanchflower, 2000), the data sets have several advantages. First, they contain very detailed and carefully collected information on important work aspects, such as income, working hours, occupation, education, industry and other individual and firm-related characteristics, which allows one to hold a multitude of work characteristics constant when investigating the procedural utility from market vs. hierarchy. Second, the European surveys include measures on job satisfaction which, for example, comparable US surveys like the Panel Study of Income Dynamics or the Current Population Survey do not. Job satisfaction, however, is needed as a proxy for utility from work. Third, two of the three surveys have a 
panel structure that can be exploited in the empirical analysis: our GSOEP sample covers the years from 1984-2000 and the BHPS sample 1991-1999, and individuals can generally be observed over several waves. And fourth, the use of surveys from three different countries gives a broader picture of the robustness of the estimated effects than when just one country is looked at. Although the three surveys come from different sources, they have a similar structure, which makes it possible to make meaningful comparisons of the respective results. ${ }^{1}$

As the dependent variable in the empirical analysis, job satisfaction is used as a proxy for the utility people derive from their work. In the German GSOEP, job satisfaction is assessed using the following question: "How satisfied are you today with the following areas of your life: your job?“ Individuals are asked to state their job satisfaction on a scale from 0 (totally unhappy) to 10 (totally happy). The question asked in the British BHPS is similar: "All things considered, how satisfied or dissatisfied are you with your present job overall?" Answers are coded here on a somewhat narrower scale from 1 (not satisfied at all) to 7 (completely satisfied). In Switzerland, the related question is "On a scale from 0 'not at all satisfied' to 10 'completely satisfied', can you indicate your degree of satisfaction with your job in general?" The question was only asked in 1999, which leaves one year of observation available for Switzerland.

In general, individuals in the countries considered seem to be quite satisfied with their jobs. In West Germany, over the period from 1984-2000, average job satisfaction of the individuals included in our sample was 7.25 (st.d. 2.00) on a scale from 0 to 10 (see the descriptive statistics in Table A in the appendix). In Britain, from 1991-1999, workers were even somewhat more satisfied with their jobs, indicating an average value of 5.43 (st.d. 
1.36) on a scale from 1-7. Job satisfaction was highest in Switzerland in 1999, where the average worker stated a job satisfaction score of 8.10 (st.d 1.72) on a scale from 0 to 10 .

The first step of the analysis is focused on a comparison between self-employed and employed people. The dummy 'self-employed' takes on the value 1 when individuals state that they are self-employed in a given year, and is 0 when people in the workforce are employed by an organization. In constructing the variable 'self-employed', we follow the employment classifications specified in the respective surveys, without making any additional adjustments to the self-employment category. Following this procedure, in West Germany an average 8.3 percent of the total workforce sampled in the GSOEP was selfemployed in the years from 1984-2000, and this ratio was relatively constant over the period (min 7.5\%, max. 9.9\%). In Britain, an average 12.0 percent of the workforce was self-employed during the years from 1991-1999 (min. $11.0 \%$, max $12.5 \%$ ). In Switzerland the ratio amounted to 10.5 percent in $1999 .^{2}$

The three surveys contain detailed information on important control variables. Total personal income of an individual is used to account for effects of income on job satisfaction. The influence of working hours is measured by using the total hours an individual works in an average week (including overtime hours). Apart from these core control variables, the surveys include information on tenure (the time spent in the present job or employment position), age, gender, education, whether people work part-time or fulltime, and which occupation and industry they work in. This creates a large and detailed set of control variables. In the GSOEP, for example, there is information on 7 categories of education, 88 categories of different occupations, and 45 industry categories. Similar sets of 
control variables are available for the BHPS and the SHP. An overview of the descriptive statistics for each of the three different data sets are given in the appendix (Table A).

In the second step of the empirical analysis, additional information is used that is somewhat less comparable across the different data sets than the variables already described. In particular, the size of the organization that individuals work in will be incorporated in a further analysis of procedural utility effects from hierarchy. This data is contained in all three surveys, but the scaling of the variable differs to some extent. Some of the further empirical analysis will also be carried out using the BHPS only, because this survey contains some interesting questions on particular aspects of people's jobs that the other two surveys do not contain.

\section{EMpirical ANALysis}

\section{A. Basic Regressions}

Table I presents descriptive statistics on the differences in job satisfaction between selfemployed and employed individuals, and it contains the basic regressions on the effects of self-employment on job satisfaction. For all three countries considered, the raw differences show statistically significantly higher job satisfaction for self-employed workers. The difference is smallest in the case of West Germany ( 0.21 index points on a scale from $0-10$, $\mathrm{p}<0.001)$ and reaches similar magnitude in Britain $(0.21$ index points on a scale from $1-7$, $\mathrm{p}<0.001)$ and Switzerland (0.42 index points on a scale from $0-10, \mathrm{p}<0.001)$. These differences, however, might reflect a multitude of characteristics that distinguish selfemployed individuals from employed people. The question whether higher job satisfaction 
among the self-employed can be attributed to procedural utility has thus to be investigated in more detail.

In a first step, multivariate regressions are run that include the control variables discussed in the data section. This accounts for differences between self-employed and employed people that are unrelated to procedural utility. For example, it could be that self-employed people work in systematically different jobs and industries than employees, which may make them more satisfied with their jobs. Furthermore, the regressions control for important outcome aspects of work, in particular income and working hours. The basic regressions presented in table I are estimated using an ordered logit model, as job satisfaction is an ordinally scaled dependent variable. The weighting variables applied allow representative results on the subject level for the respective country. ${ }^{3}$ Moreover, in the case of the German and British panel, the estimated robust standard errors are corrected for repeated observations on the individual level over time.

\section{TABLE I ABOUT HERE}

The multivariate regressions confirm that the self-employed are more satisfied with their jobs than employees, even when a multitude of work characteristics are controlled for, including income and working hours. ${ }^{4}$ For all three countries, substantial and highly significant effects are found. Their size is comparable to the raw differences also indicated in table I. ${ }^{5}$ This corroborates results previously reported by e.g. Blanchflower (2000), Blanchflower et al. (2001) and Blanchflower and Oswald (1998). Before moving to a deeper investigation of procedural utility, it seems warranted to extend the previous 
research and more precisely address the question of whether higher job satisfaction among self-employed persons is indeed a robust result.

\section{B. Analyzing the Job Satisfaction Effects of Self-Employment in Depth}

One concern with the regressions reported in table I is that self-employed people may be a selection of people that have a natural tendency to be more satisfied with their jobs, or are in other respects different than employees. The estimated coefficients might then not reflect non-monetary benefits from being self-employed, but merely personality differences between the two groups. This concern is addressed using two different methodologies.

\section{Fixed effects estimates}

First, individual fixed effects regressions are run for West Germany and Britain, where the panel structure of the surveys allows one to observe the same persons moving into selfemployment or out of it. We use a linear fixed effects estimator, as ordered-logit fixed effects estimators are not yet commonly available (but comparisons of the two estimation techniques seem to indicate similar results, Ferrer-i-Carbonell and Frjiters, 2004). The results from these linear fixed effects regressions show that the job satisfaction effects of self-employment are a robust phenomenon. Table II contains three different specifications for each country. In a first step, the same specifications as in table II are estimated including individual fixed effects (model I). The results indicate that people who either move in or out of self-employment are on average more satisfied with their jobs when they are self-employed. The estimated coefficients for the variable 'self-employed' are of somewhat smaller magnitude than those reported in table I, but still statistically significant. ${ }^{6}$ 


\section{TABLE II ABOUT HERE}

One aspect not captured by model I, however, is that it might make a difference whether one enters or leaves self-employment. Model II allows for such differences by splitting up changers into three subgroups: those who become self-employed and stay self-employed during the observation period ("in-movers"), those who leave self-employment and stay employed during the observation period ("out-movers"), and those who change more than once between employment and self-employment ("multiple changers"). This partitioning can also address further concerns about selection; arguably, the first group can be considered as those who become entrepreneurs and successfully stay so, while the second group might leave self-employment and stay employed for equally good reasons (e.g. because they somehow failed). The results from model II show that for both West Germany and Britain, the major part of the self-employment effect indeed stems from those people that become self-employed and stay so. "In-movers" report major and highly significant increases in job satisfaction after having moved into self-employment. "Multiple changers" also report somewhat higher job satisfaction when they are self-employed, although this result is only statistically significant for the British sample. In contrast, "out-movers" become slightly more satisfied with their jobs after they have left self-employment (although not significantly). The estimates thus indicate that "in-movers" as well as "outmovers" improve their job situation after a change, but the first group much more so than the second, resulting in an average positive effect of being self-employed.

One concern with the estimates for the "in-movers" might be that they just reflect a successful change in the job situation, an effect that also people who simply change jobs 
possibly experience. To rule this alternative explanation out, model III compares "inmovers" to a group of employed people that changes exactly once to a new firm during the observation period. These "job changers" are likely to be a suitable comparison group because they successfully change jobs, sticking with their new employer. The results from model III show that "job changers" indeed report significantly increased job satisfaction after moving to a new firm. Nevertheless, the positive effects are much smaller than those for people who become self-employed (the coefficients on the variables "in-movers" and "job changers" are significantly different at any conventional levels). As well, the coefficients for the "job changers" are of similar size as the coefficients for "out-movers" (model II), i.e. people moving out of self-employment do not improve their job satisfaction more than employed people who change jobs. Thus, for both West Germany and Britain, we find robust evidence that people moving into self-employment enjoy higher utility from their work, even when unobserved individual heterogeneity, the effects of a shift in the job situation, and changes in material outcomes are controlled for.

\section{A "natural experiment" on self-employment creation}

The second approach applied here to study the job satisfaction effects of self-employment takes advantage of a unique situation that created a sort of "natural experiment" on selfemployment creation. After the fall of the Berlin wall in 1989, East Germany experienced a fundamental and largely unexpected change in the structure of its economy. Notably with respect to self-employment, the situation changed dramatically: for the first time it became a realistic option for East Germans. Self-employment was severely restricted under the socialist regime in the German Democratic Republic, because it did not fit into a socialist economic system. As a consequence, the ratio of self-employment in the workforce is 
estimated at a low 2.1\% for the last year of the GDR (Lechner and Pfeiffer, 1993). East Germans were first sampled in the GSOEP in 1990 and every year thereafter. The GSOEP thus offers the unique possibility to observe the developments in self-employment and its consequences in the ex-GDR regions after 1989. Of course, the fall of the Berlin Wall did not create a natural experiment in the sense that people where chosen randomly to become self-employed. Rather, the lifting of the iron curtain created a fundamental exogenous change in restrictions on self-employment.

\section{TABLE III ABOUT HERE}

Table III summarizes the results from this "natural experiment" on self-employment creation. It can be observed that the sudden absence of restrictions on self-employment indeed created a steady and substantial rise in the ratio of self-employed people in the workforce. Already in 1990 , the ratio had risen from $2.1 \%$ to $3.4 \%$, and it grew to $7.3 \%$ in the three years until 1993. Afterwards the ratio approached a stable $7.5 \%-8.5 \%$, converging approximately to the ratios of self-employment found in West Germany at this time. What were the effects on job satisfaction that the people flowing into selfemployment experienced? The results presented in table III indicate that they are substantial. The ordered logit regressions for the East German workforce presented contain the same variables as the one for West Germany in table I and are run separately for every year. For the first year 1990, the group of self-employed people is split into those that were in self-employment already before 1989, and those that became self-employed right after the lifting of the iron curtain. This is possible because in the first wave of the GSOEP that sampled East Germans (1990), individuals were asked whether they had become self- 
employed after December 1989, or whether they had been self-employed already before. For the years after 1990, only the net effect for all self-employed people is presented.

The effects of becoming self-employed can most strikingly be illustrated by those people who moved into self-employment right in 1990. Their job satisfaction is by a magnitude higher than that of employed East Germans at the time (the estimated coefficient of 1.340 amounts to approx. 1.5 index points on a job satisfaction scale from 0-10). This effect is not due to a generally low job satisfaction among the employed in East Germany working in still mainly socialist firms; in fact, the average job satisfaction in the East German work force was as high in 1990 as in West Germany (7.20 vs. 7.25); it only dropped sharply afterwards (probably because of the onset of privatizations and tougher economic conditions like rising unemployment). Moreover, it is not the case that intrinsically more satisfied people were more likely to become self-employed after the fall of the Berlin wall. The 1990 regression includes a variable on the "life satisfaction five years ago"; it captures the answers of East Germans to the question of how they rated their general satisfaction with life back in the GDR times in 1985. If only intrinsically satisfied (or dissatisfied) people would have become self-employed after the fall of the iron curtain, the inclusion of this variable would lower the estimated coefficient on the 'newly self-employed' to zero. Table III furthermore indicates that, for every year, a positive and mostly significant coefficient of being self-employed is estimated; this shows that the large share of people moving into self-employment indeed enjoyed higher subsequent job satisfaction than their counterparts who had remained employed over the period (over and above outcomes like income or working hours). The results also hold if a fixed effects model for the whole period from 1990-2000 is estimated (which again only considers observed 'changers' from 
employment into self-employment and vice versa in the estimation of the self-employed coefficient).

To summarize the results so far, the fixed effects and the "natural experiment" approaches presented lead us to conclude that self-employed persons are indeed more satisfied with their jobs. Moreover, this cannot be attributed to material benefits from work, as the regressions control for important outcome variables like income or working hours.

\section{Testing the Effects of Hierarchy Size}

Before moving to a more detailed investigation of whether the high job satisfaction among the self-employed can be attributed to procedural utility, we shall investigate the second theoretical hypothesis advanced: people working in small firms enjoy higher procedural utility at work than people working in large firms. Table IV contains the same job satisfaction regressions as in table I for West Germany, Great Britain and Switzerland, but they are augmented with information on the size of the hierarchy individuals work in (i.e., the total number of people working in an organization).

The results reported in table IV show two main findings. First, the self-employment - job satisfaction effect is to a large extent due to the fact that self-employed persons so far have been compared to a heterogeneous group of employed people. Once this heterogeneity among employees with respect to firm size is taken into account, the coefficient on the variable self-employed is lowered by about one sixth in the case of West Germany, by about two thirds in the case of Britain, and by over a half in the case of Switzerland. This means that the self-employed are substantially more satisfied with their job than employees because the average employee works in a larger hierarchy, which seems to constitute a 
disutility. In fact, the median employee in West Germany works in a firm with 100-200 workers, and the median self-employed person in a firm with 5-19 workers; in the United Kingdom, the median employee is employed in a firm with 50-99 workers, and the median self-employed person works in a firm with 1-2 workers; and in Switzerland, the numbers are 25-49 workers and 1-4 workers, respectively. A different way to highlight this finding is to estimate the job satisfaction regressions only for the subsample of persons that work in small firms (e.g., the two smallest firm size categories). If this restriction is applied, the estimated coefficients for the variable self-employed amount to 0.190 in the case of West Germany ( $\mathrm{p}<0.05$ ), to 0.014 in Great Britain (n.s.), and to 0.349 in Switzerland ( $\mathrm{p}=0.065$ ). In other words, the self-employed are more satisfied with their jobs than employees working in small firms, but not consistently so.

As a second main result, the regressions in table IV present clear evidence that job satisfaction is decreasing with the size of a firm in all three countries, other things equal. This is an interesting result in itself, which has not been much noted in the literature so far (exceptions are Idson, 1990; Lalive, 2002 for the United States and Gardner, 2001, for Great Britain). Notably for Great Britain and Switzerland, the effects of hierarchy size are substantial. Dissatisfaction from hierarchy seems to peak at a firm size of about 200-500, and then slightly decreases again as firms get bigger. These findings correspond nicely to the well established fact that larger firms pay higher wages (Oi and Idson, 1999). May there be similar reasons why the self-employed are happier with their jobs, and people working in smaller firms are more satisfied with their work than employees in large organizations? 


\section{A Direct Test for Procedural Utility}

In the last part of the empirical analysis, we exploit the fact that in the British Household Panel, employees as well as self-employed people were asked some unique questions on their satisfaction with different aspects of work. The questions can be divided into two rather outcome-oriented ones, and two concerned with procedural aspects of work. With respect to the first, individuals were asked to state on a scale from 1-7 their satisfaction with their "job security", and also their satisfaction with their workload ("the hours you work"). With respect to the second, the questions asked how satisfied individuals were with "being able to use their own initiative" and the "actual work itself". Whereas job security and workload are outcome aspects of work, the use of initiative and the actual work itself are closely linked to aspects or work that, according to the theoretical foundations outlined in section II, are sources of procedural utility. Being able to use one's own initiative is a core characteristic of self-determination; similarly, having a rewarding work content strongly relates to the individual need of competence. Thus, these two work aspects should be well suited to capture procedural utility at work.

\section{TABLE V ABOUT HERE}

Table $\mathrm{V}$ presents six regressions. In a first set of three regressions, it is analyzed whether the self-employment - job satisfaction effect can be explained by outcome-related or by procedural aspects of work. In a second set of regressions, the same analysis is conducted for the firm size - job satisfaction relationship, considering the group of employees separately. In the respective first columns, a baseline specification of the job satisfaction 
regression is shown excluding work-related aspects. In the middle columns, the regressions are re-estimated including the two outcome-related domain satisfaction variables as explanatory variables. In the third columns, the regressions are re-estimated including the two domain satisfaction variables on procedural aspects of work.

The results presented in table $\mathrm{V}$ indicate that both the self-employment - job satisfaction effect and the firm size - job satisfaction effect can to a large part be explained by procedural characteristics of work, but not by outcome-related aspects. Consider, first, the relationship between self-employment and job satisfaction. Although the two variables on satisfaction with outcome-related aspects of work are highly correlated with job satisfaction, they cannot explain why the self-employed are more satisfied with their jobs than employees. Rather, the effects of self-employment on job satisfaction tend to get larger when these variables are included in the regression. In contrast, when the two procedural domain satisfaction measures are included in the regression, it shows that they explain the self-employment - job satisfaction effect completely. This is strong evidence that procedural utility is the reason why the self-employed are more satisfied with their jobs than employees.

A similar result emerges when the same analysis is conducted for the firm size - job satisfaction relationship. Outcome-related work aspects cannot account for the finding that employees working in smaller firms are more satisfied with their work than people employed in large firms. In contrast, the negative effect of firm size on job satisfaction is reduced by about two thirds once the variables on procedural work characteristics are included in the regression (see also Idson, 1990 for related results). Thus, it can be 
concluded that procedural disutility from being subject to a more intense hierarchy explains a large part of the job dissatisfaction among people employed in larger firms. ${ }^{7}$

\section{Conclusions}

Procedural utility is a concept that extends the outcome-oriented approach to human wellbeing in economics. It proposes that people have preferences about how outcomes are generated. In this paper, the concept of procedural utility is applied to institutions, in particular to the two most important decision-making mechanisms of the economy, the market and hierarchy. Nowadays, most production and employment in developed countries is integrated into organizations based on at least some extent of hierarchical decisionmaking. Still, a considerable share of employment is independently undertaken in the form of self-employment. We empirically test whether the self-employed value their position as independent actors on the market, and of not being subject to a hierarchy, as a source of procedural utility. Our results confirm this hypothesis; they furthermore show that the existence of procedural utility also explains a considerable part of the related finding that people working in large organizations are less satisfied with their work than people working in small firms.

Our study not only provides a more general view of the utility gained from work, but it also has implications for policy. Following the results reached here, the government should at least not restrict self-employment opportunities. In many countries, bureaucratic barriers for self-employment are high. Djankow et al. (2002), for example, show for a large sample of nations that administrative laws and regulations are often restrictive, making it costly for citizens to set up their own businesses. At the same time, large numbers of people in the industrial countries say they would prefer to be self-employed (Blanchflower et al., 2001). 
Lowering barriers to entry thus seems to be a simple means to promote self-employment, providing individuals with added, procedural, utility. There might also be a case for financial state intervention, as insufficient access to credit seems to be another important reason why many people do not become self-employed (e.g. Blanchflower and Oswald, 1998). However, such programs also have costs that would have to be balanced against their procedural utility effects.

In a more general view, the results presented in this paper may contribute to a better understanding of what individuals value. We submit that individuals gain utility from procedures over and above the outcome that is thereby generated. In particular, we show that self-employment is a source of procedural utility, compared to being subject to a hierarchy. 


\section{REFERENCES}

BENZ, M. (2007). The Relevance of Procedural Utility for Economics. In: B.S. Frey and A. Stutzer (eds.). Economics and Psychology. A Promising New Cross-Disciplinary Field. MIT Press, forthcoming.

BERTRAND, M. and MUllainAthAN, S. (2001). Do People Mean What They Say? Implications for Subjective Survey Data. American Economic Review, 91(2), 67-72.

BLANCHFLOWER, D.G. (2000). Self-employment in OECD countries. Labour Economics, 7, 471-505.

and OSWALD, A.J. (1998). What Makes an Entrepreneur? Journal of Labor Economics, 16(1), 26-60.

and (1999). Well-Being, Insecurity and the Decline of American Job Satisfaction. Working Paper, University of Warwick.

and STUTZER, A. (2001). Latent Entrepreneurship across Nations. European Economic Review, 45, 680-691.

BRITISH HOUSEHOLD PANEL SURVEY (2000). [computer file]. Principal investigator:

ESRC Research Centre on Micro-social Change. Colchester: The Data Archive [distributor]. Data files and associated documentation.

CLARK, A.E. (2001). What really matters in a job? Hedonic measurement of quit data. Labour Economics, 8, 223-242. (2003). Looking for Labour Market Rents Using Subjective Data. Working Paper,

Delta, Paris. and OSWALD, A.J. (1994). Unhappiness and Unemployment. Economic Journal, 104(424), 648-659. , GEORGELLIS, Y. and SANFEY, P. (2001). Scarring: The Psychological Impact of Past Unemployment. Economica, 68(270), 221-41.

CROPANZANO, R.S., KACMAR, M.K. and BOZEMAN, D.P. (1995). The Social Setting of Work Organizations: Politics, Justice, and Support. In: R.S. Cropanzano and M.K. Kacmar (eds.). Organizational Politics, Justice, and Support: Managing Social Climate at Work. Westport: Greenwood, 1-18.

DAHL, R.A. and LINDBLOM, C.L. (1953). Politics, Economics and Welfare. Harper, New York.

DJANKOW, S., LA PORTA, R., LOPEZ-DE-SILANES, F. and SHLEIFER, A. (2002). The Regulation of Entry. Quarterly Journal of Economics, 117(1), 1-37.

FERRER-I-CARBONELL, A. and FRIJTERS, P. (2004). The Effect of Metholodogy on the Determinants of Happiness. Economic Journal, 114, 641-659.

FREY, B.S., BENZ, M. and STUTZER, A. (2004). Introducing Procedural Utility: Not Only What, But Also How Matters. Journal of Institutional and Theoretical Economics, 160(3), 377-401. and STUTZER, A. (2002). What Can Economists Learn from Happiness Research? Journal of Economic Literature, 40, 402-435.

and (2004). Economic Consequences of Mispredicting Utility. University of

Zurich, Institute for Empirical Research in Economic Working Paper No. 218. and _ (2005). Beyond Outcomes: Measuring Procedural Utility. Oxford Economic

Papers, 57(1), 90-111. 
GARDNER, J. (2001). An Outline of the Determinants of Job Satisfaction. University of Warwick, Doctoral Thesis.

HAMERMESH, D. (1977). Economic Aspects of Job Satisfaction. In: O. Ashenfelter and W. Oates (eds.). Essays in Labor Market Analysis. New York: John Wiley.

HAMILTON, B.H. (2000). Does Entrepreneurship Pay? An Empirical Analysis of Returns to Self-Employment. Journal of Political Economy, 108(3), 604-632.

HUNDLEY, G (2001). Why and When Are the Self-Employed More Satisfied With Their Work? Industrial Relations, 40(2), 293-317.

IDSON, T.L. (1990). Establishment Size, Job Satisfaction and the Structure of Work. Applied Economics, 22, 1007-1018.

JOULFAIAN, D. and RIDER, M. (1998). Differential taxation and tax evasion by small business. National Tax Journal, 51(4), 675-687.

KAHNEMAN, D., WAKKER, P.P. and SARIN, R. (1997). Back to Bentham? Explorations of Experienced Utility. Quarterly Journal of Economics, 112(2), 375-405.

KAWAGUCHI, D. (2002). Compensating wage differentials among self-employed workers: evidence from job satisfaction scores. Institute of Social and Economic Research, Osaka University, Discussion Paper No. 568.

LALIVE, R. (2002). Do Wages Compensate for Workplace Amenities? Working paper, Institute for Empirical Research in Economics, University of Zurich.

LAYARD, R. (2005). Happiness: Lessons from a New Science. New York: Penguin Press.

LECHNER, M. and PFEIFFER, F. (1993). Der Weg in die selbständige Erwerbstätigkeit am Beginn der Marktwirtschaft. ZEW Wirtschaftsanalysen 1: 45-65.

LIND, E.A. and TYLER, T.R. (1988). The Social Psychology of Procedural Justice. New York: Plenum Press.

MOSKOVITZ, T.J. and VISSING-JORGENSEN, A. (2002). The Returns to Entrepreneurial Investment: A Private Equity Premium Puzzle? American Economic Review, 92(4), 745-778.

OI, W.Y. and IDSON, T.L. (1999). Firm Size and Wages. In: O. Ashenfelter and D. Card (eds.). Handbook of Labor Economics, Volume 3. North Holland, Amsterdam, 21652214.

OSWALD, A.J. (1997). Happiness and Economic Performance. Economic Journal, 107(445), 1815-1831.

PFEFFER, J. (1981). Power in Organizations. Marshfield: Pitman.

PUGH, D.S., HICKSON, D.H., HININGS, R.C. and TURNER, C. (1968). Dimensions of Organizational Structure. Administrative Science Quarterly, 13(1), 65-105.

RYAN, R.M. and DECI, E.L. (2000). The "What" and "Why" of Goal Pursuits: Human Needs and the Self-determination of Behavior. Psychological Inquiry, 11(4), 227-268.

SCHMINKE, M., AMBROSE, M.L. and CROPANZANO, R.S. (2000). The Effect of Organizational Structure on Perceptions of Procedural Fairness. Journal of Applied Psychology, 85(2), 294-304.

SOEP GROUP (2001). The German Socio-Economic Panel (GSOEP) after more than 15 years - Overview. In: E. Holst, D.R. Lillard and T.A. DiPrete (eds.). Proceedings of the 2000 Fourth International Conference of German Socio-Economic Panel Study Users (GSOEP2000). Vierteljahrshefte zur Wirtschaftsforschung, 70 (1), 7-14.

VISCUSI, W.K. (1993). The Value of Risks to Life and Health. Journal of Economic Literature, 31(4), 1912-1946. 
WARR, P. (1999). Well-Being and the Workplace. In: D. Kahneman, E. Diener and N. Schwarz (eds). Well-Being: The Foundations of Hedonic Psychology. New York: Russell Sage Foundation, 392-412.

WILLIAMSON, O.E. (1975). Markets and Hierarchies: Analysis and Antitrust Implications. New York: Free Press.

WILLIAMSON, O.E. (1985). The Economic Institutions of Capitalism. Firms, Markets, Relational Contracting. New York: Free Press.

WINKELMANN, L. and WINKELMANN, R. (1998). Why Are the Unemployed So Unhappy? Evidence from Panel Data. Economica, 65 (257), 1-15. 


\section{ENDNOTES}

${ }^{1}$ It is noteworthy that the analyses presented here could be extended in future work by using data contained in the European Community Household Panel (ECHP), which covers 15 European countries.

${ }^{2}$ These self-employment ratios are computed using the full samples of all people in the workforce. In the samples actually used in the empirical analysis (as indicated in table A), the actual ratio of self-employed people is somewhat lower in the case of West Germany than in the full sample (5.6\%), essentially because self-employed people seem to be more reluctant to state their income. This potentially induces problems of measurement error which are discussed in the empirical section. For the BHPS and the SHP, self-employment ratios in the final samples are similar to those in the full samples. Overall, the ratios are comparable to those presented in other studies, e.g. Blanchflower, Oswald and Stutzer (2001), which indicate self-employment ratios of $10.1 \%$ for West Germany, $13.6 \%$ for Britain and $13.6 \%$ for Switzerland.

${ }^{3}$ The weights used are panel weights controlling for panel attrition in case of the GSOEP, and cross-sectional weights in case of the BHPS and the SHP.

${ }^{4}$ One caveat to be made is that potential measurement errors might bias the results. As already indicated in footnote 1 in the data section, self-employed people are relatively more reluctant to state their income than employed people, and it has also been found that they tend to underreport their incomes (e.g. Joulfaian and Rider 1998 for the US). However, such measurement errors seem not to be a major problem for our estimates. If the regressions in table I (and all the other regressions in this paper) are estimated excluding the income and working time variables, the self-employment results remain qualitatively very similar. This is also important because income and wages have to be considered as endogenous variables in the context of this study.

${ }^{5}$ Strictly, the results have to be interpreted by looking at the marginal effects for each variable, as the estimated coefficients of an ordered logit regression do not have any intuitive interpretation. The marginal effects for the variable "self-employed", indicating the change of the probability that an individual is more satisfied with work by one point when he or she is self-employed rather than employed, are $2.0 \%$ for Germany, $4.5 \%$ for UK and $8.7 \%$ for Switzerland (probability change for the highest score of the job satisfaction variable). The magnitude of the marginal effects can more easily be assessed, however, if, for 
simplicity, one uses an OLS estimator rather than ordered logit. The estimated coefficients for the variable „self-employed“ from OLS-regressions are 0.22 for Germany, 0.16 for UK, and 0.28 for Switzerland.

${ }^{6}$ Note that the variable ,self-employed' only captures job satisfaction changes for people that either move from employment into self-employment or from self-employment into employment. People that change from unemployment (or non-employment) into self-employment and vice versa are not included in the sample, basically because there are no job satisfaction measures available for individuals that do not have a job.

${ }^{7}$ The results in table $\mathrm{V}$ remain qualitatively very similar if the regressions are run using a fixed effects estimator controlling for unobserved individual heterogeneity. Note also that the regression in the third columns contain less observations than the ones in the left and middle columns, because the question on the "use of initiative" was not asked in 1998 and 1999. The results, however, remain largely unchanged if the regressions in the left and middle columns are estimated with the reduced sample of 1991-1997. 
TABLE I

\section{SELF-EMPLOYMENT AND JOB SATISFACTION IN GERMANY, GREAT BRITAIN AND SWITZERLAND}

\section{DEPENDENT VARIABLE: JOB SATISFACTION}

\begin{tabular}{|c|c|c|c|c|c|c|}
\hline \multirow[b]{2}{*}{ Variable } & \multicolumn{2}{|c|}{ West Germany } & \multicolumn{2}{|c|}{ Great Britain } & \multicolumn{2}{|c|}{ Switzerland } \\
\hline & $\begin{array}{c}\text { mean job } \\
\text { satisfaction } \\
\text { (scale } 0-10 \text { ) }\end{array}$ & $\begin{array}{c}\text { ordered } \\
\text { logit } \\
\text { regression }\end{array}$ & $\begin{array}{l}\text { mean job } \\
\text { satisfaction } \\
\text { (scale 1-7) }\end{array}$ & $\begin{array}{c}\text { ordered } \\
\text { logit } \\
\text { regression }\end{array}$ & $\begin{array}{c}\text { mean job } \\
\text { satisfaction } \\
\text { (scale } 0-10 \text { ) }\end{array}$ & $\begin{array}{c}\text { ordered } \\
\text { logit } \\
\text { regression }\end{array}$ \\
\hline Self-employed & $\begin{array}{l}7.45^{* *} \\
(1.92)\end{array}$ & $\begin{array}{l}0.196^{* *} \\
(0.064)\end{array}$ & $\begin{array}{l}5.61 * * \\
(1.31)\end{array}$ & $\begin{array}{l}0.278^{* *} \\
(0.056)\end{array}$ & $\begin{array}{l}8.47 * * \\
(1.77)\end{array}$ & $\begin{array}{l}0.418^{* *} \\
(0.112)\end{array}$ \\
\hline Employed & $\begin{array}{c}7.24 \\
(2.01)\end{array}$ & ref. group & $\begin{array}{c}5.40 \\
(1.37)\end{array}$ & ref. group & $\begin{array}{l}8.05 \\
(1.71)\end{array}$ & ref. group \\
\hline $\begin{array}{l}\text { Total net income } \\
(\log )\end{array}$ & & $\begin{array}{c}0.374 * * \\
(0.035)\end{array}$ & & $\begin{array}{c}0.081 * * \\
(0.021)\end{array}$ & & $\begin{array}{c}0.050 \\
(0.061)\end{array}$ \\
\hline $\begin{array}{l}\text { Working hours per } \\
\text { week }\end{array}$ & & $\begin{array}{c}-0.022 * * \\
(0.004)\end{array}$ & & $\begin{array}{l}-0.007^{\circ} \\
(0.004)\end{array}$ & & $\begin{array}{c}-0.036^{* *} \\
(0.012)\end{array}$ \\
\hline (Working hours) $^{2}$ & & $\begin{array}{l}0.0001 * * \\
(0.0000)\end{array}$ & & $\begin{array}{l}0.0001^{\circ} \\
(0.0000)\end{array}$ & & $\begin{array}{r}0.0004 * * \\
(0.0001)\end{array}$ \\
\hline Working part-time & & $\begin{array}{l}-0.035 \\
(0.032)\end{array}$ & & $\begin{array}{l}0.401 * * \\
(0.064)\end{array}$ & & $\begin{array}{c}-0.367 * * \\
(0.123)\end{array}$ \\
\hline Tenure & & $\begin{array}{c}-0.013^{* *} \\
(0.004)\end{array}$ & & $\begin{array}{c}-0.029^{* *} \\
(0.006)\end{array}$ & & $\begin{array}{c}0.010 \\
(0.012)\end{array}$ \\
\hline Tenure $^{2}$ & & $\begin{array}{l}0.0003 * \\
(0.0001)\end{array}$ & & $\begin{array}{l}0.0007 * * \\
(0.0002)\end{array}$ & & $\begin{array}{l}-0.0003 \\
(0.0003)\end{array}$ \\
\hline Age & & $\begin{array}{c}-0.035^{* *} \\
(0.009)\end{array}$ & & $\begin{array}{c}-0.066^{* *} \\
(0.007)\end{array}$ & & $\begin{array}{l}-0.036^{\circ} \\
(0.020)\end{array}$ \\
\hline $\mathrm{Age}^{2}$ & & $\begin{array}{l}0.0004 * * \\
(0.0001)\end{array}$ & & $\begin{array}{l}0.001 * * \\
(0.0001)\end{array}$ & & $\begin{array}{c}0.0007 * * \\
(0.0002)\end{array}$ \\
\hline Sex (Female) & & $\begin{array}{l}0.079 * \\
(0.039)\end{array}$ & & $\begin{array}{c}0.308^{* *} \\
(0.041)\end{array}$ & & $\begin{array}{l}0.287 * * \\
(0.092)\end{array}$ \\
\hline Education & & 7 categ. & & 12 categ. & & 10 categ. \\
\hline Job dummies & & 88 categ. & & 73 categ. & & 31 categ. \\
\hline Industry dummies & & 45 categ. & & 10 categ. & & 14 categ. \\
\hline Year dummies & & 17 categ. & & 9 categ. & & - \\
\hline No. of observations & & $70 ‘ 229$ & & $52^{\prime} 022$ & & $3 ‘ 431$ \\
\hline No. of individuals & & $11^{\prime} 700$ & & $13 ‘ 380$ & & $3 ‘ 431$ \\
\hline Time period & & $1984-2000$ & & $1991-1999$ & & 1999 \\
\hline $\mathrm{F}$ & & $5.85^{* *}$ & & $13.84^{* *}$ & & $3.38 * *$ \\
\hline
\end{tabular}

Notes: Weighted ordered logit regressions. Robust standard errors in parentheses (corrected for repeated observations on individuals). Significance levels: ${ }^{\circ} 0.05<\mathrm{p}<0.1, * 0.01<\mathrm{p}<0.05, * * \mathrm{p}<0.01$.

Data sources: GSOEP 1984-2000, BHPS 1991-1999, SHP 1999. 
TABLE II

SELF-EMPLOYMENT AND JOB SATISFACTION:

FIXED EFFECTS REGRESSIONS FOR GERMANY AND GREAT BRITAIN

DEPENDENT VARIABLE: Job SATISFACTION

\begin{tabular}{|c|c|c|c|c|c|c|}
\hline \multirow[t]{2}{*}{ Variable } & \multicolumn{3}{|c|}{ West Germany } & \multicolumn{3}{|c|}{ Great Britain } \\
\hline & Model I & Model II & Model III & Model I & Model II & Model III \\
\hline $\begin{array}{l}\text { Self-employed } \\
\text { (SE) }\end{array}$ & $\begin{array}{l}0.111^{\circ} \\
(0.058)\end{array}$ & & & $\begin{array}{c}0.162 * * \\
(0.035)\end{array}$ & & \\
\hline $\begin{array}{l}\text { In-Movers } \\
(1=\text { periods when } S E)\end{array}$ & & $\begin{array}{c}0.347 * * \\
(0.098)\end{array}$ & $\begin{array}{c}0.405^{* *} \\
(0.099)\end{array}$ & & $\begin{array}{c}0.350^{* *} \\
(0.060)\end{array}$ & $\begin{array}{c}0.369^{* *} \\
(0.060)\end{array}$ \\
\hline $\begin{array}{l}\text { Out-Movers } \\
(1=\text { periods when } S E)\end{array}$ & & $\begin{array}{l}-0.202 \\
(0.156)\end{array}$ & & & $\begin{array}{l}-0.059 \\
(0.069)\end{array}$ & \\
\hline $\begin{array}{l}\text { Multiple changers } \\
(1=\text { periods when } S E)\end{array}$ & & $\begin{array}{c}0.043 \\
(0.083)\end{array}$ & & & $\begin{array}{l}0.141^{*} \\
(0.062)\end{array}$ & \\
\hline $\begin{array}{l}\text { Job changers } \\
(1=\text { periods at new firm })\end{array}$ & & & $\begin{array}{c}0.142 * * \\
(0.036)\end{array}$ & & & $\begin{array}{c}0.068 * * \\
(0.023)\end{array}$ \\
\hline Total net income $(\log )$ & $\begin{array}{c}0.461^{* *} \\
(0.030)\end{array}$ & $\begin{array}{c}0.459^{* *} \\
(0.030)\end{array}$ & $\begin{array}{c}0.454^{* *} \\
(0.030)\end{array}$ & $\begin{array}{c}0.041^{* *} \\
(0.011)\end{array}$ & $\begin{array}{c}0.042^{* *} \\
(0.011)\end{array}$ & $\begin{array}{c}0.039^{* *} \\
(0.011)\end{array}$ \\
\hline Working hours per week & $\begin{array}{l}-0.007 * \\
(0.003)\end{array}$ & $\begin{array}{l}-0.006^{\circ} \\
(0.003)\end{array}$ & $\begin{array}{c}-0.007 * * \\
(0.003)\end{array}$ & $\begin{array}{r}-0.0008 \\
(0.002)\end{array}$ & $\begin{array}{l}-0.0009 \\
(0.002)\end{array}$ & $\begin{array}{l}-0.0009 \\
(0.002)\end{array}$ \\
\hline (Working hours) $^{2}$ & $\begin{array}{c}0.0000 \\
(0.0000)\end{array}$ & $\begin{array}{c}0.0000 \\
(0.0000)\end{array}$ & $\begin{array}{c}0.0000 \\
(0.0000)\end{array}$ & $\begin{array}{c}0.0000 \\
(0.0000)\end{array}$ & $\begin{array}{c}0.0000 \\
(0.0000)\end{array}$ & $\begin{array}{c}0.0000 \\
(0.0000)\end{array}$ \\
\hline Working part-time & $\begin{array}{l}-0.015 \\
(0.025)\end{array}$ & $\begin{array}{l}-0.014 \\
(0.025)\end{array}$ & $\begin{array}{l}-0.013 \\
(0.025)\end{array}$ & $\begin{array}{l}0.080^{*} \\
(0.035)\end{array}$ & $\begin{array}{l}0.080^{*} \\
(0.035)\end{array}$ & $\begin{array}{l}0.082 * \\
(0.035)\end{array}$ \\
\hline Tenure & $\begin{array}{c}-0.049 * * \\
(0.004)\end{array}$ & $\begin{array}{c}-0.049^{* *} \\
(0.004)\end{array}$ & $\begin{array}{c}-0.046 * * \\
(0.004)\end{array}$ & $\begin{array}{c}-0.056^{* *} \\
(0.003)\end{array}$ & $\begin{array}{c}-0.055^{* *} \\
(0.003)\end{array}$ & $\begin{array}{c}-0.054^{* *} \\
(0.003)\end{array}$ \\
\hline Tenure $^{2}$ & $\begin{array}{c}0.0008 * * \\
(0.0001)\end{array}$ & $\begin{array}{c}0.0008^{* *} \\
(0.0001)\end{array}$ & $\begin{array}{r}0.0008 * * \\
(0.0001)\end{array}$ & $\begin{array}{l}0.001 * * \\
(0.0001)\end{array}$ & $\begin{array}{l}0.001 * * \\
(0.0001)\end{array}$ & $\begin{array}{l}0.001 * * \\
(0.0001) \\
\end{array}$ \\
\hline No. of obs, & $70 ` 229$ & $70 ‘ 229$ & $70^{`} 028$ & $52^{\prime} 022$ & $52^{\prime} 022$ & $52^{`} 022$ \\
\hline No. of individ. & $11^{\prime} 700$ & $11 ‘ 700$ & $11^{\prime} 668$ & $13 ‘ 380$ & $13 ‘ 380$ & $13 ‘ 380$ \\
\hline Avg. obs. per individual & 6.0 & 6.0 & 6.0 & 3.9 & 3.9 & 3.9 \\
\hline $\mathrm{F}$ & $14.24 * *$ & $14.13^{* *}$ & $14.32 * *$ & $9.17 * *$ & $9.18 * *$ & $9.29 * *$ \\
\hline
\end{tabular}

Notes: OLS regressions with individual fixed effects. In addition to the variables shown, the regressions include the same variables for age, education, job, industry, and year as in table I. Significance levels: ${ }^{\circ} 0.05<\mathrm{p}<0.1, * 0.01<$ $\mathrm{p}<0.05, * * \mathrm{p}<0.01$.

Data sources: GSOEP 1984-2000, BHPS 1991-1999. 


\section{TABLE III}

\section{SELF-EMPLOYMENT AND Job SATISFACTION - RESUltS FROM A “NATURAL EXPERIMENT” IN EAST GERMANY}

\section{DEPENDENT VARIABLE: JOB SATISFACTION}

\begin{tabular}{|c|c|c|c|c|c|c|c|c|c|c|c|c|c|c|}
\hline \multicolumn{15}{|c|}{ East Germany } \\
\hline Year & 1990 & 1990 & 1991 & 1992 & 1993 & 1994 & 1995 & 1996 & 1997 & 1998 & 1999 & 2000 & $\begin{array}{l}1990- \\
2000\end{array}$ & $\begin{array}{l}\text { Fixed } \\
\text { Effects }\end{array}$ \\
\hline $\begin{array}{l}\text { Ratio self- } \\
\text { employed / } \\
\text { workforce }\end{array}$ & $3.4 \%$ & $3.4 \%$ & $5.3 \%$ & $6.1 \%$ & $7.2 \%$ & $7.3 \%$ & $7.5 \%$ & $8.0 \%$ & $8.6 \%$ & $8.2 \%$ & $8.4 \%$ & $8.0 \%$ & & \\
\hline $\begin{array}{l}\text { Self-employed } \\
\text { (SE) }\end{array}$ & $\begin{array}{c}0.853 * * \\
(0.256)\end{array}$ & - & $\begin{array}{c}0.287 \\
(0.273)\end{array}$ & $\begin{array}{c}0.698 * * \\
(0.266)\end{array}$ & $\begin{array}{l}0.462^{\circ} \\
(0.271)\end{array}$ & $\begin{array}{c}0.371 \\
(0.263)\end{array}$ & $\begin{array}{l}0.406^{\circ} \\
(0.239)\end{array}$ & $\begin{array}{l}0.546^{*} \\
(0.239)\end{array}$ & $\begin{array}{l}0.442^{\circ} \\
(0.243)\end{array}$ & $\begin{array}{c}0.245 \\
(0.224)\end{array}$ & $\begin{array}{l}0.376^{\circ} \\
(0.227)\end{array}$ & $\begin{array}{c}0.425^{\circ} \\
(0.225)\end{array}$ & $\begin{array}{c}0.384 * * \\
(0.118)\end{array}$ & $\begin{array}{c}0.656^{* *} \\
(0.116)\end{array}$ \\
\hline $\begin{array}{l}\text { Was SE before } \\
\text { "Wende" }\end{array}$ & - & \begin{tabular}{l|}
$0.708 *$ \\
$(0.290)$
\end{tabular} & & & & & & & & & & & & \\
\hline $\begin{array}{l}\text { Became SE after } \\
\text { "Wende" }\end{array}$ & - & $\begin{array}{c}1.446 * * \\
(0.432)\end{array}$ & & & & & & & & & & & & \\
\hline $\begin{array}{l}\text { Total income } \\
(\log )\end{array}$ & $\begin{array}{l}0.354^{*} \\
(0.142)\end{array}$ & $\begin{array}{c}0.367 * * \\
(0.142)\end{array}$ & $\begin{array}{l}0.585 * * \\
(0.139)\end{array}$ & $\begin{array}{c}0.925 * * \\
(0.137)\end{array}$ & $\begin{array}{c}0.609 * * \\
(0.145)\end{array}$ & $\begin{array}{l}1.031 * * \\
(0.160)\end{array}$ & $\begin{array}{c}0.965 * * \\
(0.137)\end{array}$ & $\begin{array}{c}0.913 * * \\
(0.161)\end{array}$ & $\begin{array}{c}0.556 * * \\
(0.152)\end{array}$ & $\begin{array}{c}0.575 * * \\
(0.117)\end{array}$ & $\begin{array}{c}0.542 * * \\
(0.118)\end{array}$ & $\begin{array}{c}0.613 * * \\
(0.119)\end{array}$ & $\begin{array}{c}0.573 * * \\
(0.057)\end{array}$ & $\begin{array}{c}0.367 * * \\
(0.050)\end{array}$ \\
\hline $\begin{array}{l}\text { Working hours } \\
\text { per week }\end{array}$ & $\begin{array}{l}-0.038^{\circ} \\
(0.021)\end{array}$ & $\begin{array}{c}-0.038^{\circ} \\
(0.021)\end{array}$ & $\begin{array}{c}0.079 * * \\
(0.018)\end{array}$ & $\begin{array}{l}-0.010 \\
(0.023)\end{array}$ & $\begin{array}{c}0.008 \\
(0.023)\end{array}$ & $\begin{array}{c}-0.070 * * \\
(0.027)\end{array}$ & $\begin{array}{l}-0.015 \\
(0.019)\end{array}$ & $\begin{array}{l}-0.004 \\
(0.024)\end{array}$ & $\begin{array}{c}0.007 \\
(0.024)\end{array}$ & $\begin{array}{l}-0.018 \\
(0.018)\end{array}$ & $\begin{array}{c}0.003 \\
(0.016)\end{array}$ & $\begin{array}{l}-0.015 \\
(0.022)\end{array}$ & $\begin{array}{c}0.003 \\
(0.009)\end{array}$ & $\begin{array}{c}0.027 * * \\
(0.008)\end{array}$ \\
\hline (Working hours) $^{2}$ & $\begin{array}{l}0.0006 * \\
(0.0002)\end{array}$ & $\begin{array}{c}0.0006 * \\
(0.0002)\end{array}$ & $\begin{array}{c}- \\
0.0007 * * \\
(0.0002)\end{array}$ & $\begin{array}{c}0.0002 \\
(0.0002)\end{array}$ & $\begin{array}{l}0.0000 \\
(0.002)\end{array}$ & $\begin{array}{l}0.0008 * * \\
(0.0003)\end{array}$ & $\begin{array}{c}0.0002 \\
(0.0002)\end{array}$ & $\begin{array}{c}0.0000 \\
(0.0003)\end{array}$ & $\begin{array}{l}-0.0002 \\
(0.0002)\end{array}$ & $\begin{array}{c}0.0001 \\
(0.0002)\end{array}$ & $\begin{array}{l}-0.0001 \\
(0.0002)\end{array}$ & $\begin{array}{c}-0.0000 \\
(0.0002)\end{array}$ & $\begin{array}{l}-0.0000 \\
(0.0001)\end{array}$ & $\begin{array}{l}-0.0002 * \\
(0.0001)\end{array}$ \\
\hline $\begin{array}{l}\text { Life satisfaction } 5 \\
\text { years before }\end{array}$ & - & $\begin{array}{c}0.112 * * \\
(0.015)\end{array}$ & & & & & & & & & & & & \\
\hline No. of obs. & 2’675 & 2'675 & 2’077 & 1'917 & 1'720 & 1'633 & 1'716 & 1'600 & 1'581 & 1'767 & 1'732 & 1'646 & $20 ’ 064$ & $20 ’ 064$ \\
\hline $\mathrm{Chi}^{2} / \mathrm{F}$ & $250.9 * *$ & $310.4 * *$ & $262.4 * *$ & $290.7 * *$ & $267.6^{* *}$ & $219.4 * *$ & $267.0 * *$ & $202.7 * *$ & $213.9 * *$ & $182.8 * *$ & $176.2 * *$ & $191.7 * *$ & $3.53 * *$ & $4.14 * *$ \\
\hline
\end{tabular}

Notes: Ordered logit regressions. Standard errors in parentheses. The fixed effects regression is OLS, and the regression for the years $1990-2000$ is ordered logit with robust standard errors. In addition to the variables shown, the regressions include variables on age, age squared, sex, and dummies for education, job, industry, and year, as in table I for West Germany. Significance levels: ${ }^{\circ} 0.05<\mathrm{p}<0.1, * 0.01<\mathrm{p}<0.05, * * \mathrm{p}<0.01$. Data source: GSOEP $1990-2000$. 


\section{TABLE IV}

\section{Testing The Effects of Hierarchy Size}

DEPENDENT VARIABLE: Job SATISFACTION

\begin{tabular}{|c|c|c|c|c|c|c|c|c|}
\hline \multicolumn{3}{|c|}{ West Germany } & \multicolumn{3}{|c|}{ United Kingdom } & \multicolumn{3}{|c|}{ Switzerland } \\
\hline Variable & $\begin{array}{l}\text { Coefficient on } \\
\text { self-employed } \\
\text { from table I }\end{array}$ & $\begin{array}{c}\text { Regression } \\
\text { including } \\
\text { hierarchy size }\end{array}$ & Variable & $\begin{array}{l}\text { Coefficient on } \\
\text { self-employed } \\
\text { from table I }\end{array}$ & $\begin{array}{c}\text { Regression } \\
\text { including } \\
\text { hierarchy size }\end{array}$ & Variable & $\begin{array}{l}\text { Coefficient on } \\
\text { self-employed } \\
\text { from table I }\end{array}$ & $\begin{array}{c}\text { Regression } \\
\text { including } \\
\text { hierarchy size }\end{array}$ \\
\hline Self-employed & $\begin{array}{c}0.196 * * \\
(0.064)\end{array}$ & $\begin{array}{l}0.162 * \\
(0.066)\end{array}$ & $\begin{array}{l}\text { Self- } \\
\text { employed }\end{array}$ & $\begin{array}{c}0.278 * * \\
(0.056)\end{array}$ & $\begin{array}{c}0.089 \\
(0.071)\end{array}$ & $\begin{array}{l}\text { Self- } \\
\text { employed }\end{array}$ & $\begin{array}{c}0.418 * * \\
(0.112)\end{array}$ & $\begin{array}{c}0.157 \\
(0.125)\end{array}$ \\
\hline $\begin{array}{l}\text { Hierarchy size } \\
\text { (size of firm) }\end{array}$ & & & $\begin{array}{l}\text { Hierarchy } \\
\text { size } \\
\text { (size of firm) }\end{array}$ & & & $\begin{array}{l}\text { Hierarchy } \\
\text { size } \\
\text { (size of firm) }\end{array}$ & & \\
\hline$<5$ persons & & ref. group & $\begin{array}{l}1-2 \\
\text { persons }\end{array}$ & & ref. group & $\begin{array}{l}1-4 \\
\text { persons }\end{array}$ & & ref. group \\
\hline $5-19$ & & $\begin{array}{l}-0.016 \\
(0.045)\end{array}$ & $3-9$ & & $\begin{array}{l}-0.046 \\
(0.064)\end{array}$ & $5-9$ pers & & $\begin{array}{l}-0.244^{\circ} \\
(0.144)\end{array}$ \\
\hline $20-99$ & & $\begin{array}{l}-0.102 * \\
(0.041)\end{array}$ & $10-24$ & & $\begin{array}{c}-0.233 * * \\
(0.069)\end{array}$ & $10-19$ & & $\begin{array}{c}-0.435^{* *} \\
(0.153)\end{array}$ \\
\hline $100-200$ & & $\begin{array}{c}-0.134 * * \\
(0.046)\end{array}$ & $25-49$ & & $\begin{array}{c}-0.207 * * \\
(0.073)\end{array}$ & $20-24$ & & $\begin{array}{c}-0.391 * \\
(0.190)\end{array}$ \\
\hline $200-2000$ & & $\begin{array}{c}-0.140 * * \\
(0.045)\end{array}$ & $50-99$ & & $\begin{array}{c}-0.318 * * \\
(0.074)\end{array}$ & $25-49$ & & $\begin{array}{c}-0.505 * * \\
(0.154)\end{array}$ \\
\hline \multirow[t]{4}{*}{$>2000$} & & $\begin{array}{l}-0.114^{*} \\
(0.051)\end{array}$ & $100-199$ & & $\begin{array}{c}-0.401 * * \\
(0.076)\end{array}$ & $50-99$ & & $\begin{array}{c}-0.581 * * \\
(0.154)\end{array}$ \\
\hline & & & $200-499$ & & $\begin{array}{c}-0.417 * * \\
(0.073)\end{array}$ & $100-499$ & & $\begin{array}{c}-0.798 * * \\
(0.142)\end{array}$ \\
\hline & & & $500-999$ & & $\begin{array}{c}-0.397 * * \\
(0.081)\end{array}$ & $500-999$ & & $\begin{array}{c}-0.727 * * \\
(0.187)\end{array}$ \\
\hline & & & $>1000$ & & $\begin{array}{c}-0.418 * * \\
(0.073)\end{array}$ & $>1000$ & & $\begin{array}{c}-0.594 * * \\
(0.160)\end{array}$ \\
\hline Total net & & $0.395 * *$ & Total net & & $0.103 * *$ & Total net & & 0.079 \\
\hline income (log) & & $(0.035)$ & income (log) & & $(0.021)$ & income (log) & & $(0.064)$ \\
\hline Working hours & & $-0.021 * *$ & Working & & -0.006 & Working & & $-0.034 * *$ \\
\hline per week & & $(0.004)$ & hours / week & & $(0.004)$ & hours / week & & $(0.012)$ \\
\hline
\end{tabular}


TABLE IV (CONTINUED)

\begin{tabular}{|c|c|c|c|c|c|}
\hline (Working & $0.0001^{*}$ & (Working & 0.0001 & (Working & $0.0004 * *$ \\
\hline hours) ${ }^{2}$ & $(0.0001)$ & hours) $)^{2}$ & $(0.0001)$ & hours) $)^{2}$ & $(0.0001)$ \\
\hline Working part- & -0.036 & Working & $0.384 * *$ & Working & $-0.387 * *$ \\
\hline time & $(0.032)$ & part-time & $(0.065)$ & part-time & $(0.127)$ \\
\hline Tenure & $\begin{array}{c}-0.012 * * \\
(0.004)\end{array}$ & Tenure & $\begin{array}{c}-0.029 * * \\
(0.006)\end{array}$ & Tenure & $\begin{array}{c}0.012 \\
(0.012)\end{array}$ \\
\hline Tenure $^{2}$ & $\begin{array}{l}0.0002^{\circ} \\
(0.0001)\end{array}$ & Tenure $^{2}$ & $\begin{array}{c}0.0008 * * \\
(0.0002)\end{array}$ & Tenure $^{2}$ & $\begin{array}{c}-0.0003 \\
(0.0003)\end{array}$ \\
\hline Age & $\begin{array}{c}-0.035^{* *} \\
(0.009)\end{array}$ & Age & $\begin{array}{c}-0.065^{* *} \\
(0.007)\end{array}$ & Age & $\begin{array}{c}-0.035(*) \\
(0.020)\end{array}$ \\
\hline $\mathrm{Age}^{2}$ & $\begin{array}{c}0.0004 * * \\
(0.0001)\end{array}$ & $\mathrm{Age}^{2}$ & $\begin{array}{l}0.001 * * \\
(0.0001)\end{array}$ & $\operatorname{Age}^{2}$ & $\begin{array}{c}0.0006^{* *} \\
(0.0002)\end{array}$ \\
\hline Sex (Female) & $\begin{array}{l}0.077 * \\
(0.039)\end{array}$ & Sex (Female) & $\begin{array}{c}0.305^{* *} \\
(0.041)\end{array}$ & Sex (Female) & $\begin{array}{c}0.295 * * \\
(0.095)\end{array}$ \\
\hline No. of obs. & $70 ’ 130$ & No. of obs. & $51^{\prime} 001$ & No. of obs. & 3'346 \\
\hline No. of ind. & $11^{\prime} 674$ & No. of ind. & $13 ' 192$ & No. of ind. & 3'346 \\
\hline Time period & $1984-2000$ & Time period & $1991-1999$ & Time period & 1999 \\
\hline $\mathrm{F}$ & $5.74 * *$ & $\mathrm{~F}$ & $13.05 * *$ & $\mathrm{~F}$ & $3.42 * *$ \\
\hline
\end{tabular}


TABLE V

\section{Procedural Utility In SELF-EMPLOYMENT AND DEPENDENT EMPLOYMENT: A DiRECT EMPIRICAL TeST \\ DEPENDENT VARIABLE: Job SATISFACTION}

\begin{tabular}{|c|c|c|c|c|c|c|}
\hline \multirow[b]{2}{*}{ Variable } & \multicolumn{6}{|c|}{ Great Britain } \\
\hline & $\begin{array}{l}\text { Baseline } \\
\text { regression }\end{array}$ & $\begin{array}{l}\text { Regr. incl. } \\
\text { outcome } \\
\text { aspects }\end{array}$ & $\begin{array}{l}\text { Regr. incl. } \\
\text { procedural } \\
\text { aspects }\end{array}$ & $\begin{array}{l}\text { Baseline } \\
\text { regression }\end{array}$ & $\begin{array}{l}\text { Regr. incl. } \\
\text { outcome } \\
\text { aspects }\end{array}$ & $\begin{array}{l}\text { Regr. incl. } \\
\text { procedural } \\
\text { aspects }\end{array}$ \\
\hline Self-employed & $\begin{array}{l}0.278 * * \\
(0.056)\end{array}$ & $\begin{array}{l}0.424^{* *} \\
(0.048)\end{array}$ & $\begin{array}{c}0.013 \\
(0.053)\end{array}$ & - & - & - \\
\hline \multicolumn{7}{|l|}{ Firm size } \\
\hline $1-2$ persons & & & & ref. group & ref. group & ref. group \\
\hline $3-9$ & & & & $\begin{array}{c}-0.296 * * \\
(0.080)\end{array}$ & $\begin{array}{c}-0.285^{* *} \\
(0.074)\end{array}$ & $\begin{array}{l}-0.198^{*} \\
(0.081)\end{array}$ \\
\hline $10-24$ & & & & $\begin{array}{c}-0.493 * * \\
(0.084)\end{array}$ & $\begin{array}{c}-0.439 * * \\
(0.077)\end{array}$ & $\begin{array}{l}-0.185^{*} \\
(0.083)\end{array}$ \\
\hline $25-49$ & & & & $\begin{array}{c}-0.456^{* *} \\
(0.086)\end{array}$ & $\begin{array}{c}-0.414 * * \\
(0.079)\end{array}$ & $\begin{array}{l}-0.172 * \\
(0.085)\end{array}$ \\
\hline $50-99$ & & & & $\begin{array}{c}-0.558 * * \\
(0.087)\end{array}$ & $\begin{array}{c}-0.530 * * \\
(0.080)\end{array}$ & $\begin{array}{l}-0.175^{*} \\
(0.087)\end{array}$ \\
\hline $100-199$ & & & & $\begin{array}{c}-0.652 * * \\
(0.088)\end{array}$ & $\begin{array}{c}-0.593 * * \\
(0.081)\end{array}$ & $\begin{array}{c}-0.232 * * \\
(0.086)\end{array}$ \\
\hline $200-499$ & & & & $\begin{array}{c}-0.658 * * \\
(0.086)\end{array}$ & $\begin{array}{c}-0.590 * * \\
(0.080)\end{array}$ & $\begin{array}{c}-0.234 * * \\
(0.086)\end{array}$ \\
\hline $500-999$ & & & & $\begin{array}{c}-0.639 * * \\
(0.093)\end{array}$ & $\begin{array}{c}-0.548 * * \\
(0.087)\end{array}$ & $\begin{array}{c}-0.237 * * \\
(0.096)\end{array}$ \\
\hline$>1000$ & & & & $\begin{array}{c}-0.663 * * \\
(0.092)\end{array}$ & $\begin{array}{c}-0.557 * * \\
(0.085)\end{array}$ & $\begin{array}{l}-0.175^{\circ} \\
(0.091)\end{array}$ \\
\hline \multicolumn{7}{|l|}{$\begin{array}{l}\text { Satisfaction with } \\
\text { outcome aspects }\end{array}$} \\
\hline Job security & - & $\begin{array}{l}0.399 * * \\
(0.009)\end{array}$ & - & & $\begin{array}{l}0.411 * * \\
(0.010)\end{array}$ & \\
\hline $\begin{array}{l}\text { Work load (hours } \\
\text { worked) }\end{array}$ & - & $\begin{array}{c}0.747 * * \\
(0.011)\end{array}$ & - & & $\begin{array}{l}0.742 * * \\
(0.012)\end{array}$ & \\
\hline \multicolumn{7}{|l|}{$\begin{array}{l}\text { Satisfaction with } \\
\text { procedural aspects }\end{array}$} \\
\hline Use of initiative & - & - & $\begin{array}{c}0.391 * * \\
(0.013)\end{array}$ & & & $\begin{array}{c}0.406 * * \\
(0.014)\end{array}$ \\
\hline Actual work itself & - & - & $\begin{array}{l}1.070^{* *} \\
(0.017)\end{array}$ & & & $\begin{array}{l}1.056^{* *} \\
(0.018)\end{array}$ \\
\hline Total net income $(\log )$ & $\begin{array}{c}0.081 * * \\
(0.021)\end{array}$ & $\begin{array}{l}0.041 * \\
(0.020)\end{array}$ & $\begin{array}{c}0.065 * * \\
(0.022)\end{array}$ & $\begin{array}{l}0.153 * * \\
(0.035)\end{array}$ & $\begin{array}{c}0.096 * * \\
(0.033)\end{array}$ & $\begin{array}{r}0.064^{\circ} \\
(0.034)\end{array}$ \\
\hline $\begin{array}{l}\text { Working hours per } \\
\text { week }\end{array}$ & $\begin{array}{l}-0.007^{\circ} \\
(0.004)\end{array}$ & $\begin{array}{l}-0.005 \\
(0.004)\end{array}$ & $\begin{array}{c}-0.017 * * \\
(0.004)\end{array}$ & $\begin{array}{l}-0.006 \\
(0.004)\end{array}$ & $\begin{array}{l}-0.006 \\
(0.004)\end{array}$ & $\begin{array}{c}-0.016 * * \\
(0.005)\end{array}$ \\
\hline (Working hours) $^{2}$ & $\begin{array}{l}0.0001^{\circ} \\
(0.0000)\end{array}$ & $\begin{array}{l}0.0003 * * \\
(0.0001)\end{array}$ & $\begin{array}{l}0.0001^{*} \\
(0.0000)\end{array}$ & $\begin{array}{c}0.0001 \\
(0.0001)\end{array}$ & $\begin{array}{l}0.0003 * * \\
(0.0001)\end{array}$ & $\begin{array}{c}0.0001 \\
(0.0001)\end{array}$ \\
\hline No. of obs. & $52^{\prime} 022$ & $52 ’ 022$ & $37 ’ 298$ & $44^{\prime} 821$ & $44^{\prime} 821$ & $32^{\prime} 017$ \\
\hline No. of ind. & $13{ }^{\prime} 380$ & $133^{\prime} 380$ & $9 ’ 283$ & $12^{\prime} 075$ & $12^{\prime} 075$ & 8'386 \\
\hline
\end{tabular}




\begin{tabular}{lccc|ccc} 
Time period & $1991-1999$ & $1991-1999$ & $1991-1997$ & $1991-1999$ & $1991-1999$ & $1991-1997$ \\
$\mathrm{~F}$ & $13.84^{* *}$ & $80.15^{* *}$ & $69.59^{* *}$ & $12.75^{* *}$ & $65.74^{* *}$ & $58.47^{* *}$ \\
\hline
\end{tabular}

Notes: Weighted ordered logit regressions. In addition to the variables shown, the regressions include the same variables on part-time work, age, age squared, sex, and dummies for education, job, industry, and year as in table I for UK. Robust standard errors in parentheses (corrected for repeated observations on individuals). Significance levels: ${ }^{\circ} 0.05<\mathrm{p}<0.1, * 0.01<\mathrm{p}<0.05,{ }^{* *} \mathrm{p}<0.01$. Data source: BHPS 1991-1999. 


\section{APPENDIX}

TABLE A

\section{DESCRIPTIVE STATISTICS}

\begin{tabular}{|c|c|c|c|c|c|c|c|c|}
\hline \multirow[b]{3}{*}{ Variable } & \multicolumn{4}{|c|}{ Germany } & \multirow{2}{*}{\multicolumn{2}{|c|}{ United Kingdom }} & \multirow{2}{*}{\multicolumn{2}{|c|}{ Switzerland }} \\
\hline & \multicolumn{2}{|c|}{ West } & \multicolumn{2}{|c|}{ East } & & & & \\
\hline & Empl. & Self-Empl. & Empl. & Self-Empl. & Empl. & Self-Empl. & Empl. & Self-Empl. \\
\hline \multirow[t]{2}{*}{$\begin{array}{l}\text { Job satisfaction } \\
\text { (see remarks) }\end{array}$} & \multicolumn{2}{|c|}{$\begin{array}{l}7.25 \\
(2.00)\end{array}$} & \multicolumn{2}{|c|}{$\begin{array}{l}6.86 \\
(2.12)\end{array}$} & \multicolumn{2}{|c|}{$\begin{array}{c}5.43 \\
(1.36)\end{array}$} & \multicolumn{2}{|c|}{$\begin{array}{c}8.10 \\
(1.72)\end{array}$} \\
\hline & $\begin{array}{c}7.24 \\
(2.01)\end{array}$ & $\begin{array}{c}7.45 \\
(1.92)\end{array}$ & $\begin{array}{c}6.84 \\
(2.12)\end{array}$ & $\begin{array}{c}7.12 \\
(2.12)\end{array}$ & $\begin{array}{c}5.40 \\
(1.37)\end{array}$ & $\begin{array}{c}5.61 \\
(1.31)\end{array}$ & $\begin{array}{c}8.05 \\
(1.71)\end{array}$ & $\begin{array}{c}8.47 \\
(1.75)\end{array}$ \\
\hline \multirow[t]{2}{*}{$\begin{array}{l}\text { Ln of total income } \\
\text { (see remarks) }\end{array}$} & \multicolumn{2}{|c|}{$\begin{array}{l}8.06 \\
(0.59)\end{array}$} & \multicolumn{2}{|c|}{$\begin{array}{c}7.71 \\
(0.60)\end{array}$} & \multicolumn{2}{|c|}{$\begin{array}{c}6.80 \\
(0.87)\end{array}$} & \multicolumn{2}{|c|}{$\begin{array}{l}10.67 \\
(0.89)\end{array}$} \\
\hline & $\begin{array}{c}8.05 \\
(0.57)\end{array}$ & $\begin{array}{c}8.20 \\
(0.91)\end{array}$ & $\begin{array}{c}7.70 \\
(0.58)\end{array}$ & $\begin{array}{c}7.88 \\
(0.79)\end{array}$ & $\begin{array}{c}6.84 \\
(0.75)\end{array}$ & $\begin{array}{c}6.57 \\
(1.45)\end{array}$ & $\begin{array}{l}10.67 \\
(0.85)\end{array}$ & $\begin{array}{l}10.69 \\
(1.08)\end{array}$ \\
\hline \multirow[t]{2}{*}{$\begin{array}{l}\text { Working hours per } \\
\text { week }\end{array}$} & \multicolumn{2}{|c|}{$\begin{array}{l}39.70 \\
(10.84)\end{array}$} & \multicolumn{2}{|c|}{$\begin{array}{c}43.26 \\
(13.08)\end{array}$} & \multicolumn{2}{|c|}{$\begin{array}{c}37.89 \\
(15.71)\end{array}$} & \multicolumn{2}{|c|}{$\begin{array}{c}36.57 \\
(14.22)\end{array}$} \\
\hline & $\begin{array}{c}39.19 \\
(10.03)\end{array}$ & $\begin{array}{c}48.41 \\
(17.96)\end{array}$ & $\begin{array}{l}42.77 \\
(9.14)\end{array}$ & $\begin{array}{c}52.23 \\
(15.84)\end{array}$ & $\begin{array}{c}36.98 \\
(14.90)\end{array}$ & $\begin{array}{c}44.62 \\
(19.47)\end{array}$ & $\begin{array}{c}35.87 \\
(13.50)\end{array}$ & $\begin{array}{c}41.85 \\
(18.10)\end{array}$ \\
\hline \multirow[t]{2}{*}{ Working part-time } & \multicolumn{2}{|c|}{0.23} & \multirow{2}{*}{\multicolumn{2}{|c|}{-}} & \multicolumn{2}{|c|}{0.23} & \multicolumn{2}{|c|}{0.35} \\
\hline & 0.23 & 0.24 & & & 0.24 & 0.19 & 0.35 & 0.32 \\
\hline \multirow[t]{2}{*}{ Tenure } & \multicolumn{2}{|c|}{$\begin{array}{l}10.70 \\
(9.20)\end{array}$} & \multirow{2}{*}{\multicolumn{2}{|c|}{-}} & \multicolumn{2}{|c|}{$\begin{array}{c}4.80 \\
(6.49)\end{array}$} & \multicolumn{2}{|c|}{$\begin{array}{c}8.07 \\
(8.83)\end{array}$} \\
\hline & $\begin{array}{l}10.56 \\
(9.06)\end{array}$ & $\begin{array}{c}11.31 \\
(11.29)\end{array}$ & & & $\begin{array}{c}4.30 \\
(5.85)\end{array}$ & $\begin{array}{c}8.46 \\
(9.24)\end{array}$ & $\begin{array}{c}7.72 \\
(8.53)\end{array}$ & $\begin{array}{c}10.74 \\
(10.50)\end{array}$ \\
\hline \multirow[t]{2}{*}{ Age } & & $\begin{array}{l}55 \\
80)\end{array}$ & & & & $\begin{array}{l}71 \\
51)\end{array}$ & & $\begin{array}{l}.24 \\
89)\end{array}$ \\
\hline & $\begin{array}{c}39.12 \\
(11.09)\end{array}$ & $\begin{array}{c}43.31 \\
(11.21)\end{array}$ & $\begin{array}{c}39.33 \\
(10.62)\end{array}$ & $\begin{array}{l}41.96 \\
(9.30)\end{array}$ & $\begin{array}{c}36.93 \\
(12.36)\end{array}$ & $\begin{array}{c}43.45 \\
(12.12)\end{array}$ & $\begin{array}{c}38.64 \\
(11.60)\end{array}$ & $\begin{array}{c}43.71 \\
(12.80)\end{array}$ \\
\hline Sex (Female) & & 38 & & & & & & 48 \\
\hline & 0.39 & 0.30 & 0.47 & 0.36 & 0.51 & 0.29 & 0.49 & 0.38 \\
\hline Education & & teg. & & teg. & & ateg. & & ateg. \\
\hline Job dummies & 88 & ateg. & & teg. & & ateg. & & ateg. \\
\hline Industry dummies & 45 & ateg. & & teg. & & ateg. & & ateg. \\
\hline No. of obs. & & 229 & & 64 & & 022 & & 331 \\
\hline & $66 ’ 314$ & 3’915 & $19^{\prime} 029$ & 1’035 & $45^{\prime} 834$ & 6’188 & 3’081 & 350 \\
\hline No. of individ. & & 700 & & & & 380 & & 131 \\
\hline & $10^{\prime} 580$ & $1 ’ 120$ & 3’930 & 324 & $11 ’ 359$ & 2’021 & 3’081 & 350 \\
\hline Time period & 1984 & 2000 & 199 & 2000 & 1991 & 1999 & & 99 \\
\hline
\end{tabular}

Notes: Unweighted means. Standard deviations in parentheses. Job satisfaction is measured on a scale from 0 to 10 in Germany, 1 to 7 in UK, and 0 to 10 in Switzerland. The total income variable consists of gross monthly income in Germany, net monthly income in UK, and net yearly income in Switzerland. Data on tenure and parttime work is missing for East Germany.

Data sources: GSOEP 1984-2000, BHPS 1991-1999, SHP 1999. 